\title{
Morphology and morphometric relationships of the sagitta of Diapterus auratus (Perciformes: Gerreidae) from Veracruz, Mexico
}

\author{
Verónica Rivera Félix ${ }^{1}$, José Antonio Martínez-Pérez ${ }^{1}$, Jacob Rubio Molina ${ }^{1}$, Rafael Emiliano \\ Quintanar Zuñiga ${ }^{2}$ \& Jonathan Franco López ${ }^{3}$ \\ 1. Laboratorio de Zoología de la Facultad de Estudios Superiores Iztacala, UNAM. Av. de los Barrios N. ${ }^{\circ} 1$ Los Reyes \\ Iztacala, Tlalnepantla, Estado de México; azuve_799@hotmail.com, jamp55@prodigy.net.mx, \\ jacob.rubio.27@gmail.com \\ 2. Laboratorio de Fisiología Vegetal, UBIPRO, Facultad de Estudios Superiores Iztacala, UNAM. Av. de los Barrios N. ${ }^{\circ}$ \\ 1 Los Reyes Iztacala, Tlalnepantla, Estado de México; rafamilk@yahoo.com \\ 3. Laboratorio de Ecología de la Facultad de Estudios Superiores Iztacala, UNAM. Av. de los Barrios N. ${ }^{\circ} 1$ Los Reyes \\ Iztacala, Tlalnepantla, Estado de México; jonfrancol@yahoo.com
}

Received 14-X-2011. Corrected 30-V-2012. Accepted 26-VI-2012.

\begin{abstract}
Sagittae otoliths are the most studied because of their morphological variability and size; the sagittae may also have valuable taxonomic use and for D. auratus has not yet been described. In the present study we present a morphological description of the sagitta otolith and an analysis of its correlation with various morphometric parameters. The biological material was captured with a beach seine in the coasts of Alvarado and Port of Veracruz, from November 2009 to June 2010. Sagittae were extracted, cleaned, photographed (SEM and optical), and measured. The analysis included the correlations between sagitta's length and width, versus the fish standard length, height and weight, for a total of 449 fishes. The comparison between left and right sagitta showed no significant difference in both otolith length and width (t-tests, $\mathrm{p}<0.05$ ) for each sex. The right otolith was used for the correlations for both males and females and the Fisher test (d.f. 161 and 143, $\mathrm{p}<0.001$ ) showed no significant differences in the slopes and intersections between them. The otolith length vs. fish weight correlation showed a positive allometric growth in males $(b=3.9754, p<0.05)$ and females $(b=4.3168, p<0.05)$. Rev. Biol. Trop. 61 (1): 139-147. Epub 2013 March 01.
\end{abstract}

Key words: otolith, sagitta, morphometry, correlations, Veracruz, Gerreidae, Diapterus auratus, mojarra guacha, Irish Pompano.

Teleost fish have three pairs of otoliths located in the membranous labyrinth (Smale et al. 1995) at the rear of the neurocranium (Morales-Nin 2000). The labyrinth includes three semicircular canals and three compartments: saculus, utriculus and lagena; each sac contains one otolith, the lapillus, the sagitta and the asteriscus, respectively (Morales-Nin 2000, Berra \& Aday 2004, Popper et al. 2005). Otoliths are calcareous concretions in the form of aragonite (Jawad 2007, Parmentier et al. 2007), their taxonomic utility was recognized by Cuvier and their value in paleontology was first acknowledged by Koken (1884) (Tuset et al. 2008). In most teleost, the sagitta is the largest otolith and the lapillus is the smallest among the three (Paxton 2000). Sagittae also exhibit variable morphology and topography among the species (Torres et al. 2000, Jawad 2007, Battaglia et al. 2010). As a result, their use as a taxonomic character has proliferated in recent years.

Because of their chemical composition, they can withstand some degree of dissolution and often species can be recognized by distinctive morphology of the sagitta (Longenecker 2008, Tombari et al. 2010). Moreover, the resistance of otolith to deterioration made it 
possible to use them in paleontological studies (Girone et al. 2006, Battaglia et al. 2010) or in the identification of prey in stomach contents of fishes, birds or mammals (Silva et al. 2000, Palma et al. 2002, Polo \& Grijalba 2008, Biffi \& Iannacone 2010). Also, oceanographers have determined species of fishes from otoliths in sediments (Battaglia et al. 2010). The first's researchers that demonstrated a positive relationship between otolith length and fish length were Trout (1954) and Templemann \& Squires (1956). Also, studies of relationships between otolith length and fish weight have been done (Waessle et al. 2003, Baker 2006, Longenecker 2008).

One of the characteristic groups of fishes of coastal zones in the Gulf of Mexico and in the South Atlantic of the American continent belongs to the Family Gerreidae. These organisms can be found in both estuaries and coastal lagoons; generally, juveniles occur in estuaries and adults in the coastal zones (Abarca et al. 2004, Abarca et al. 2007) The morphologic characteristic that distinguish the members of this family is the extremely protusible jaws. A member of this family is Diapterus auratus, the Irish Pompano or Mojarra Guacha. In Mexico, this species, is one of the most abundant species of the Southern part of the Gulf of Mexico and is an important part of the commercial fisheries (Castillo-Rivera et al. 2005). However, in spite of their abundance, studies of their biology and anatomy are scarce (Kobelkowsky 2004). Therefore, the aim of this study was to obtain data of the correlations of otolith size (length and width) with the fish length, height and total weight, and a description of the otolith morphology of Diapterus auratus.

\section{MATERIALS AND METHODS}

The biological material was captured every month with a beach seine in the coasts of Anton-Lizardo (1903'47.40" N - 95'59'30.23" W), Alvarado (18 $46^{\prime} 3.5^{\prime \prime} \mathrm{N}-95^{\circ} 45^{\prime} 47.2^{\prime \prime}$ W), and Port of Veracruz $\left(19^{\circ} 11^{\prime} 47.55^{\prime \prime} \mathrm{N}\right.$ $96^{\circ} 07^{\prime} 43.40^{\prime \prime} \mathrm{W}$ ), from November 2009-June 2010. The taxonomic identification was based on Carpenter 2002. The fishes were measured (standard length ST, cephalic length $\mathrm{CL}$ and fish height FH) with a caliper with $\pm 0.1 \mathrm{~mm}$ precision, weighted, with a semi-analytic balance with $\pm 0.001 \mathrm{~g}$ precision and photographed.

Sagittae were removed, cleaned and photographed (SEM and optical). Otoliths were examined and described using the terminology of Tuset et al. 2008. The length, greatest distance measured from the anterior tip to the posterior edge parallel to the sulcus and width, the greatest distance from the dorsal otolith edge to the ventral one, perpendicular to the sulcus, of each sagitta were measured (Harvey et al. 2000) with the software DIGIMIZER 3.7 program. The otoliths were deposited at the Facultad de Estudios Superiores Iztacala, Universidad Nacional Autónoma de México (UNAM).

The nule hypothesis was that no difference existed between left and right sagitta and it was tested with a paired $t$-test (Echeverria 1987, Volpedo \& Thompson 1996). Linear regressions were obtained for each sex to investigate possible sexual differences. The relationships between otolith and fish sizes were determined using a least-squares linear regression for the following parameters: otolith lenght (OL) vs fish heigth (FH), otolith length (OL) vs cephalic length (CL), otolith length (OL) vs standard length (SL), and otolith width (OW) vs fish height (FH) (Echeverria 1987, Gamboa 1991, Harvey et al. 2000, Jawad 2007, Battaglia et al. 2010). Also the relationships between otolith length (OL) and fish weight (FW) were determined using a least-squares regression of the $\log$ of otolith length and weight (Volpedo \& Thompson 1996, Waessle et al. 2003) for each sex (males and females) by using Le Cren equation (Le Cren 1951, Bagenal \& Tesch 1978), that is mathematically expressed as a potential function of the weight (g), versus otolith length $(\mathrm{mm})$, according the equation $\left(\mathrm{W}=\mathrm{a} \mathrm{L}^{\mathrm{b}}\right)$.

The species growth types were determined by means of the $t$-Student test, considering the constant $b$ value or allometry coefficient (Yañez 1986), in order to verify if growth type 
matched the isometric type $(\mathrm{b}=3, \mathrm{p}<0.05)$, the following equation was used $t=(b-3) / S b$ (Sokal \& Rolf 1996), where $t=t$-student value, $b=$ slope, $S b=$ slope standard error.

A Fisher test was applied F (d.f. 161 and $143, \mathrm{p}<0.001$ ), for comparing the slopes of the estimated relations for males and females of $D$. auratus (Sokal \& Rolf 1996).

\section{RESULTS}

Otolith morphology: The sagitta of $D$. auratus is ovate; the posterior margin is rounded in contrast with the anterior margin that is angled. The dorsal margin is irregular, the ventral margin is sinuated. The sulcus acusticus is heterosulcoid, ostial and has a supramedian position; it is divided into an anterior ostium and posterior cauda by a constriction (the colum). The ostium is funnel-like, it has a cisura; the rostrum is broad and the antirostrum is small and angled. The cauda is tubular; the posterior part has slightly curved part. The crista superior in the anterior part is well developed. There is a broad dorsal depression (Fig. 1).

The sample size was 449 fishes and comprised 144 females with range of $29-191 \mathrm{~mm}$, and 305 males with range of $28-180 \mathrm{~mm} \mathrm{SL}$. The analysis of the morphometric parameters showed no significant differences between the right and left sagittae in both females $(\mathrm{t}=-0.259$, $\mathrm{p}<0.05)$ and males $(\mathrm{t}=0.442, \mathrm{p}<0.05)$. Therefore

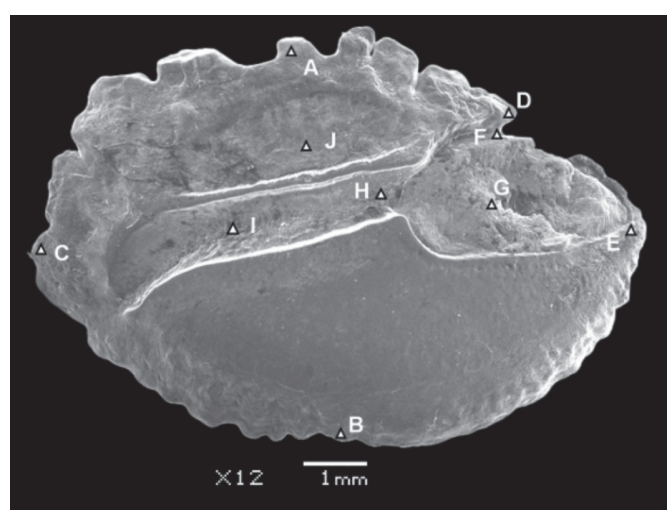

Fig. 1. SEM photography of the inner face of the left sagitta of Diapterus auratus. the right otolith was used in the regression analysis. For the OL-SL relation (Fig. $2 \mathrm{C}$ and $3 \mathrm{C}$ ) the best fit was recorded for males $\left(\mathrm{r}^{2}=0.660\right)$ while the lowest value of the coefficient of correlation was for the females $\left(\mathrm{r}^{2}=0.644\right)$. The regression analysis of the OL-FH, for each sex is shown in figure 2 (A) and $3(\mathrm{~A})$; the student $t$-test did not found significant differences between this relation in males and females. The OL-W relationship shown in figure 2 (E) and 3 (E), recorded the highest values of the coefficient of correlation with $\mathrm{r}^{2}=0.986$ for males and $\mathrm{r}^{2}=0.822$ for females. In all the cases, the models of regression used for describing the relation between otoliths and the parameters of the different measures of the fishes were appropriate, reflected on the high coefficients of correlation that oscillated between 0.71-0.98 marking a significant correlation for the slopes and intersection. The equations and coefficient of correlation obtained by the linear regression of the different measures of the otolith and the standard length and weight of $D$. auratus are shown in figure 2.

In terms of growth type, $D$. auratus shows a positive allometric growth of otolith length relative to fish weight in both males and females since the coefficient $b$, differed significantly from the theoretical value of 3 . The coefficients of determination $\left(\mathrm{R}^{2}\right)$ were similar.

The regression slopes for the measures of the sagitta in males and females showed no significant differences between sexes when comparing them with the fisher test $\left(\mathrm{F}_{(161,143 \text {, }}\right.$ $\mathrm{p}<0.001)$ (Table 1).

TABLE 1

Slope comparison (Fisher test) of males and females of the different regressions of $D$. auratus

\begin{tabular}{ccc} 
Relation & F calc & F teo $_{(161,143, p<0.001)}$ \\
OL-W & 1.163433884 & n.s. \\
OL-SL & 0.98960953 & n.s. \\
OL-CL & 0.968476642 & n.s. \\
OL-FH & 0.989393786 & n.s. \\
\hline
\end{tabular}



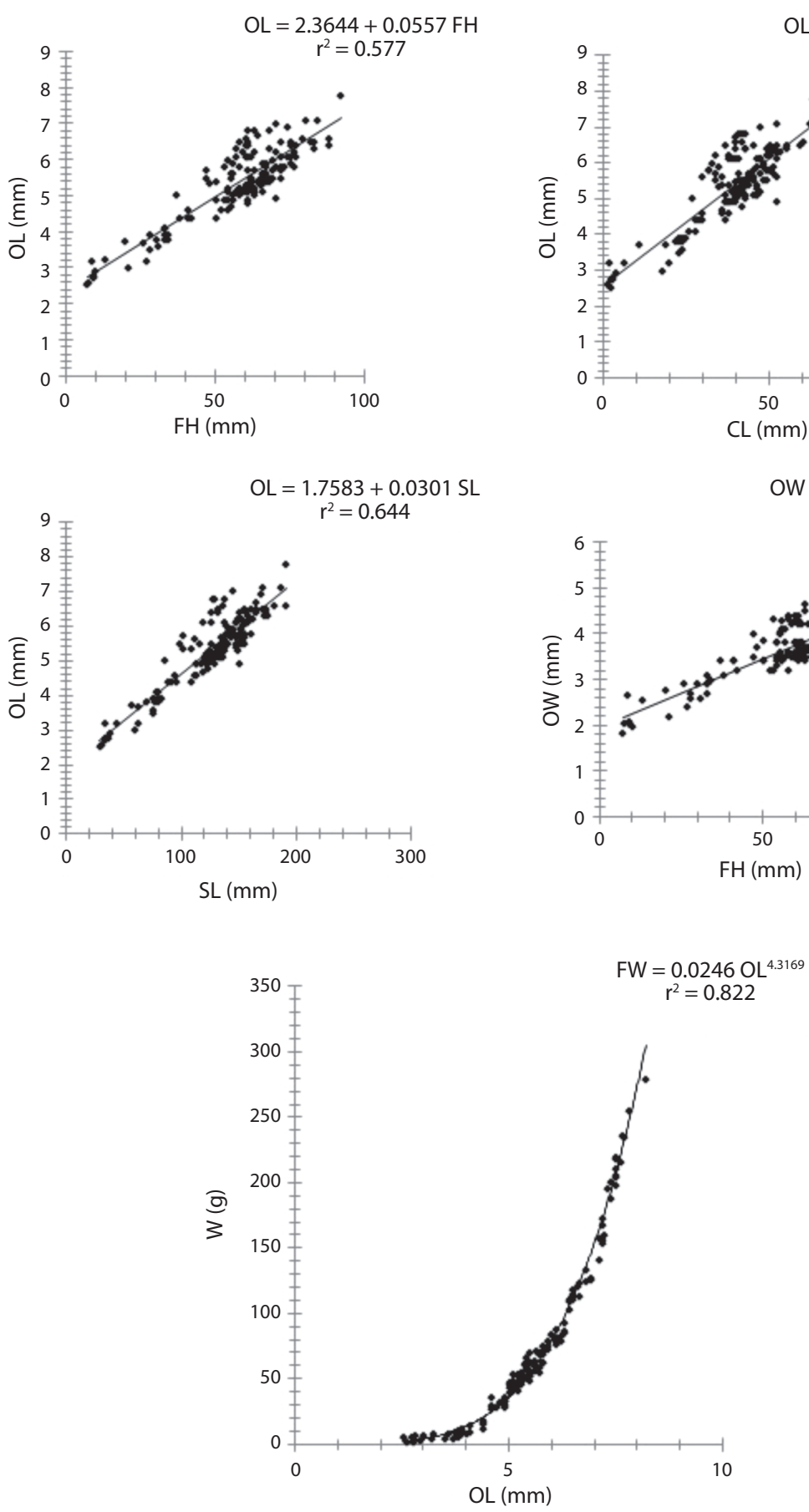

Fig. 2. (A) FH vs OL (B) CL vs OL (C) SL vs OL (D) FH vs OW (E) OL vs W for females of D. auratus. All regressions were significant at $\mathrm{p}<0.05$. 


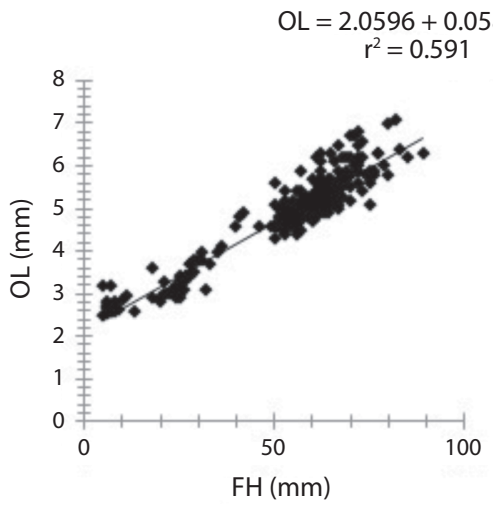

$\mathrm{OL}=1.3469+0.0330 \mathrm{SL}$

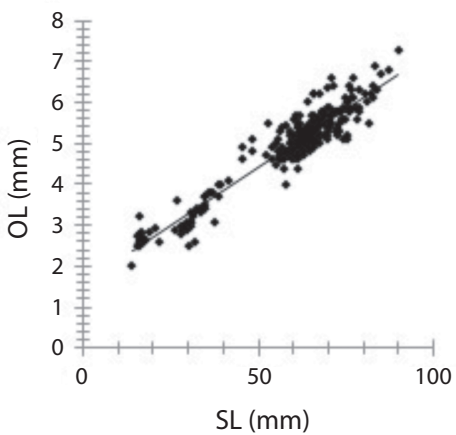

$\mathrm{SL}(\mathrm{mm})$

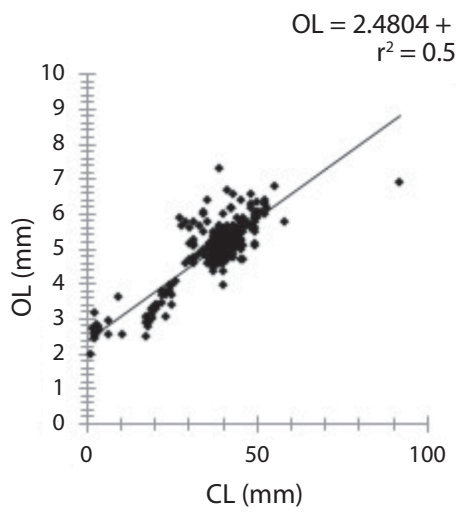

$\mathrm{OW}=1.7318+0.0349 \mathrm{FH}$

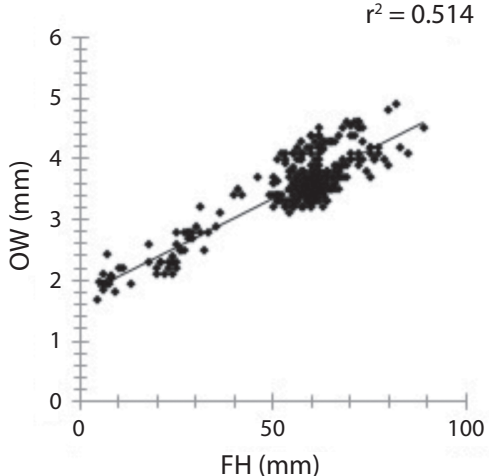

$\mathrm{FH}(\mathrm{mm})$

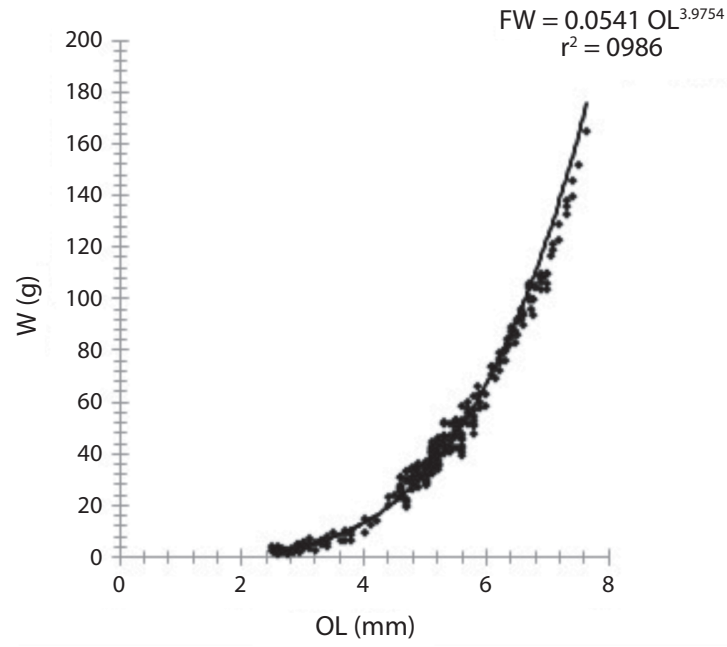

Fig. 3. (A) FH vs OL (B) CL vs OL (C) SL vs OL (D) FH vs OW (E) OL vs W for males of D. auratus. 


\section{DISCUSSION}

Diapterus auratus, is recognized as a typical species that habit coastal waters of all warm seas, they also enter to coastal lagoons and estuaries (Allen \& Robertson 1998, Arceo \& Vega 2009). In estuarine systems it is an important species throughout the year because of their numerical abundance and biomass, representing a local resource, nevertheless, information about the morphology and morphometry of otoliths of this species is scarce, and only partial information is available in some species. Sagitta otolith has been used as a taxonomical tool for identifying fishes due their large size and degree of interspecific differences (Harvey et al. 2000, Battaglia et al. 2010). Also, specific guides covering certain geographical areas have been published (Baker 2006, Tuset et al. 2008). In the present study we provide a description of the sacular otolith of $D$. auratus that allow researchers the identification of this species. The morphology of the sagitta of Gerres filamentosus, given by Baker, differs from $D$. auratus because this one is ovate, the ventral margin is sinuate and the dorsal margin is irregular. Hüssy (2008) and Stransky et al. (2008), mention that the development of the otolith in fishes, as an ontogenetic process, could be regulated by environmental factors; particularly the disponibility of food, or some other environmental factor, so that proportions of this structure could change for the same species developed in different conditions. However, considering the morphology, Kanak \& Tachihara (2006) mention that the otoliths of Gerres sp. in Okinawa, Japan, are very similar to that of Diapterus rhombeus.

Based on the results, the otoliths of $D$. auratus showed no significant differences between right and left sagitta, $(\mathrm{p}<0.05)$. The lack of significant differences between right and left sagittae is consistent with the observation that the pair of otoliths are specular images of each other (Hunt 1992), something similar was reported by Labropoulou \& Papaconstantinou (2000) for fishes of the Mediterranean.
In all the cases, the model of regression used, seemed to describe adequately the relation between otoliths and the diverse measures of fishes used, showing a high correlation of the significant estimations of slopes and intersections.

The two dimensions of otoliths examined in this study (OL and OW), showed a significant relation with fish measures: standard length and weight; Tombari et al. 2010 pointed that the size of the otoliths depends on the species.

Researchers of feeding habitats of seabirds and marine mammals need to know the morphology of otoliths and specific equations, which are useful to calculate the size and mass of prey (Echeverria 1987, Harvey et al. 2000, Berra \& Aday 2004). All equations relating otolith variables to fish standard length and fish weight for the specimens studied of $D$. auratus explained a very large proportion of the variance in the data (Table 1), these results are similar to those reported by Wassle et al. 2003, for Sciaenid species. Despite the importance of this fishes in trophic studies, their biology had not been well investigated until today.

In comparison with other similar studies on the relationship of fish and sagitta sizes (Gamboa 1991, Volpedo \& Thompson 1996, Harvey et al. 2000, Waessle et al. 2003, Jawad 2007) we tested the differences between males and females. Echeverria 1987 and Volpedo \& Thompson 1996, demonstrated that there were significant differences between males and females in some species of rockfishes and Prionotus nudigula respectively. The Fisher test $\mathrm{F}_{(161,143, \mathrm{p}<0.001)}$ for comparing the slopes of the distinct linear relations obtained for the morphometric estimations of otoliths and the records of males and females, confirm that this species did not show significant differences in the relationships between both sexes $(\mathrm{p}<0.001)$.

The study and use of otoliths for the characterization of diverse aspects of the biology of fishes has been a common practice among researchers, some have used them to characterize the stages and areas where anadromous species growth (Thresher et al. 1994, Thorrold et al. 1997, Secor et al. 1998), or for the 
determination of age of commercial fish (Radtke 1987, Lecomte 1992, Secor et al. 1995).

Paxton (2000) give some categories of fish otolith size; Perciformes, have otoliths of small to moderate size $2-5 \%$ in SL. The otolith length of $D$. auratus is consistently of $4.4 \% \mathrm{SL}$ in both males and females, this coincides with the percentage mentioned for the Perciformes.

It is recognized that the employment of otoliths in the icthiological characterization, are particularly valuable because they are not submitted to calcium reabsortion (Casselman 1990, Bordino et al. 1999, Koen et al. 1999) and their morphology is characteristic of each species (Volpedo \& Echeverría 2003), as recorded in the present study.

\section{ACKNOWLEDGMENTS}

We thank Tomas Corro Ferreira for his assistance collecting the specimens. Also we thank to all the staff of the Laboratory of Zoology at the Facultad de Estudios Superiores, Iztacala for supporting this work.

\section{RESUMEN}

Los otolitos sagitta son los más estudiados debido a su variabilidad morfológica y a su tamaño, sin embargo, los otolitos de $D$. auratus no han sido estudiados hasta el momento. En el presente estudio, se muestra una descripción completa de la morfología y un análisis morfométrico de diversas medidas. El análisis incluye las relaciones entre el ancho y largo de la sagitta contra la longitud cefálica, longitud estándar, altura y peso de 449 peces. El material biológico fue capturado con un chinchorro playero en las costas de Alvarado y el Puerto de Veracruz de noviembre 2009 a junio 2010. Las sagittae fueron extraídas, limpiadas, fotografiadas (SEM y ópticas) y medidas. La comparación entre el otolito derecho e izquierdo no mostró diferencias significativas entre el ancho y largo (prueba de $t, \mathrm{p}<0.05$ ) para cada sexo. El otolito derecho fue utilizado para las relaciones de las distintas medidas del otolito del pez y del otolito de hembras y machos; la prueba de Fisher (d.f. 161 and $143, \mathrm{p}<0.001$ ) no mostró diferencias significativas de las pendientes e intersecciones entre ellos. La relación longitud del otolito-peso del pez mostró un crecimiento de tipo alométrico positivo en machos $(b=3.9754, p<0.05)$ y hembras $(\mathrm{b}=4.3168, \mathrm{p}<0.05)$.
Palabras clave: otolito, Sagitta, Diapterus auratus, morfometría, correlaciones, Veracruz, Gerreidae, Mojarra Guacha, Irish Pompano.

\section{REFERENCES}

Abarca-Arenas, L.G., J. Franco-López, R. Chávez-López, D. Arceo-Carranza \& A. Moran-Silva. 2004. Trophic analysis of the fish community taken as bycatch of shrimp trawls off the coast of Alvarado, Mexico. Proc. Gulf Carib. Fish. Inst. 55: 384-394.

Abarca-Arenas, L.G., J. Franco-López, M.S. Peterson, N.J. Brown-Peterson \& E. Valero-Pacheco. 2007. Sociometric analysis of the role of penaids in the continental shelf food-web off Veracruz, Mexico based on bycatch. Fish Res. 87: 46-57.

Allen, G. \& D. Robertson. 1998. Peces del Pacífico Oriental Tropical. Smithsonian Tropical Research Institute, Panamá.

Arceo, C.D. \& C. M.E. Vega. 2009. Spatial and temporal characterization of fish assemblages in a tropical coastal system influenced by freshwater inputs: northwestern Yucatan península. Rev. Biol. Trop. 57: 89-103.

Bagenal, T.B. \& F.W. Tesch. 1978. Age and Growth. In: Methods for Assessment of Fish Production in Freshwater, Bagenal, T.B. Blackwell Scientific Publication, Oxford, England.

Baker, R. 2006. Piscivory and the functioning of the shallow tropical estuarine nursery grounds. Ph.D. Thesis, James Cook University, Quenlands, Australia.

Battaglia, P., D. Malara, T. Romeo \& F. Andaloro. 2010. Relationships between otolith size and fish size in some mesopelagic and bathypelagic species from the Mediterranean Sea (Strait of Messina, Italy). Sci. Mar. 74: 605-612.

Berra, T.M. \& D.D. Aday. 2004. Otolith description and age-and-growth of Kurtus gulliveri from Northern Australia. J. Fish. Biol. 65: 354-362.

Biffi, D. \& J. Iannacone. 2010. Variabilidad trófica de Lontra felina (Molina 1782) (Carnivora: Mustelidae) en dos poblaciones de Tacna (Perú) entre agosto y diciembre de 2006. Mastozoología Neotropical 17: 11-17.

Bordino, P., G. Thompson \& M. Iñíguez. 1999. Ecology and behaviour of the franciscana (Pontoporia blainvillei) in Bahía Anegada, Argentina. J. Cetacean Res. Manage. 1: 213-22.

Carpenter, K.E. 2002. The living marine resources of the western central Atlantic. Food and Agriculture Organization. Species identification guide for fisheries 
purposes and American Society of Ichthyologists and Herpetologists. Special Publication No. 5, Rome.

Casselman, J.M. 1990. Growth and relative size of calcified structures of fish. Trans. Am. Fish. Soc. 119: 673-688.

Castillo-Rivera, M., M. Montiel, L.S. Añorve \& R. Zarate. 2005. Spatial, seasonal and diel distribution patterns of two species of mojarras (Pisces: Gerreidae) in a Mexican tropical coastal lagoon. J. Appl. Ichthyol. 21: 498-503.

Echeverria, T.W. 1987. Relationship of otolith length to total length in rockfishes from Northern and Central California. Fishery Bull. 86: 383-387.

Gamboa, D.A. 1991. Otolith size versus weight and bodylength relationships for eleven fish species of Baja California, Mexico. Fishery Bull. 89: 701-706.

Girone, A., D. Nolf \& H. Cappetta. 2006. Plesitocene fish otoliths from the Mediterranean Basin: A synthesis. Geobios 39: 651-671.

Harvey, J.T., T.R. Loughlin, M.A. Perez \& D.S. Oxman. 2000. Relationship between fish size and otolith length for 63 species of fishes from the Eastern North Pacific Ocean. U.S. Department of Commerce NOAA. Technical Report NMFS 150.

Hunt, J.J. 1992. Morphological Characteristics of Otoliths for Selected Fish in the Northwest Atlantic. J. Northw. Atl. Fish. Sci. Vol. 13: 63-75.

Hüssy, K. 2008. Otolith shape in juvenile cod (Gadus morhua): Ontogenetic and environmental effects. J. Exp. Mar. Biol. Ecol. 364: 35-41.

Jawad, L.A. 2007. Comparative morphology of the otolith of the triplefins (family: Tripterygiidae). J. Nat. History 41: 901-924.

Kanak, K. \& K. Tachihara. 2006. Age and growth of Gerres sp. (Perciformes: Gerreidae) in Okinawa Island of southern Japan. Fish. Sci. 72: 932-938.

Kobelkowsky, A. 2004. Osteology of the sea mojarra, Diapterus auratus Ranzani (Teleostei: Gerreidae). Hidrobiológica 14: 1-10.

Koen, A.M., S.M. Pedraza, A.C.M. Schiavini, R.N.P. Goodall \& E.A. Crespo. 1999. Stomach contents of false killer whales (Pseudorca crassidens) stranded on coasts of the strait of Magellan, Tierra del Fuego. Mar. Mamm. Sci. 15: 712-724.

Labropoulou, M. \& C. Papaconstantinou. 2000. Community structure of deep-sea demersal fish in the North Aegean Sea (northeastern Mediterranean). Hydrobiologia 440: 281-296.

Le Cren, E. 1951. The length-weight relation and seasonal cycle in gonad weight and condition in the perch, "Perca fluvialiti". J. Anim. Ecol. 20: 201-219.
Lecomte, F.R. 1992. Growth history and age at recruitment of European glass eels Anguilla anguilla as revealed by otolith microstructure. Mar. Biol. 144: 205-210.

Longenecker, K. 2008. Relationships between otolith size and body size for hawaiian reef fishes. Pacific Sci. 62: $533-539$.

Morales-Nin, B. 2000. Review of the growth regulation processes of otolith daily increment formation. Fish. Res. 46: 53-67.

Palma, A., R. Figueroa, V.H. Ruiz, E. Araya \& P. Berríos. 2002. Composición de la dieta de Oncorhynchus mykiss (Walbaum 1792) (Pisces: Salmonidae) en un sistema fluvial de baja intervención antropica; Estero Nonguen, VIII Región, Chile. Gayana 66: 129-139.

Parmentier, E., R. Cloots, R. Warin \& C. Henrist. 2007. Otolith crystals (in arapidae): Growth and habit. J. Struct. Biol. 159: 462-473.

Paxton, J.R. 2000. Fish otoliths: Do sizes correlate with taxonomic group, habitat and/or luminiscense? Royal Soc. 355: 1299-1303.

Polo, S.C.J. \& B.L.M. Grijalba. 2008. Espectro trófico de la raya guitarra Rhinobatos percellens (Walbaum, 1792) (Elasmobranchii: Rhinobatidae) en Santa Marta, Caribe Colombia. Rev. Mem. Fund. La Salle Cien. Nat. 68: 21-33.

Popper, A.N., J. Ramcharitar \& S.E. Campana. 2005. Why otoliths? Insights from inner ear physiology and fisheries biology. Mar. Fresh. Res. 56: 497-504.

Radtke, R.L. 1987. Age and growth information available from the otoliths of the Hawaiian snapper, Pristipomoides filamentosus. Coral Reefs 6: 19-25.

Secor, D.H., T.M. Trice \& H.T. Hornick. 1995. Validation of otolith-based aging and a comparison of otolith and scale-based aging in mark-recaptured striped bass, Morone saxatilis. Fish Bull. 93: 186-190.

Secor, D.H., T. Ota \& M. Tanaka. 1998. Use of otolith microanalysis to determine estuarine migrations of Ariake Sea Japanese sea bass Lateolabrax japonicus. Fish. Sci. 64: 740-743.

Silva, M.P., R. Bastida \& C. Darrieu. 2000. Dieta de la Gaviota cocinera (Larus dominicanus) en zonas costeras de la provincia de Buenos Aires, Argentina. Ornitología Neotropical 11: 331-339.

Smale, M.J., G. Watson \& T. Hetch. 1995. Otolith Atlas of Southern African Marine Fishes. Number 1 in Ichthyological Monographs of the J.L.B. Smith Institute of Ichthyology. Grahamstown, South Africa: J.L.B. Smith Institute of Ichthyology.

Sokal, R. \& F. Rohlf. 1996. Biometry. Freeman and Company, San Francisco, USA.

Stransky, C., A.G. Murta, J. Schlickeisen \& C. Zimmermann. 2008. Otolith shape analysis as a tool for stock separation of horse mackerel (Trachurus trachurus) 
in the Northeast Atlantic and Mediterranean. Fish. Res. 89: 159-166.

Templemann, W. \& H.J. Squires. 1956. Relationship of otolith lengths and weights in the haddock, Melanogrammus aeglefinus (L.), to the growth of the fish. J. Fish. Res. Board Can. 13: 467-487.

Thorrold, S.R., C.M. Jones \& S.E. Campana. 1997. Response of otolith microchemistry to environmental variations experienced by larval and juvenile Atlantic croaker Micropogonias undulates. Limn. Oceanogr. 42: 102-111.

Thresher, R.E., C.H. Proctor, J.S. Gunn \& I.R. Harrowfield. 1994. An evaluation of electron-probe microanalysis of otoliths for stock delineation and identification of nursery areas in a southern temperate groundfish, Nemadactylus macropterus (Cheilodactylidae). Fish. Bull. 92: 817-840.

Tombari, A.D., A. Gosztony, D.D. Echeverria \& A.V. Volpedo. 2010. Otolith and vertebral morphology of marine atherinid species (Atheriniformes, Atherinopsidae) coexisting in the southwestern Atlantic Ocean. Ciencias Marinas 36: 213-223.

Torres, G.J., A. Lombarte \& B. Morales-Nin. 2000. Variability of the sulcus acusticus in the sagittal otolith of the genus Merluccius (Merluccidae). Fish. Res. 46: 5-13.

Trout, G.C. 1954. Otolith growth of the Barents Sea cod. Rapp. P-v. Reun. Cons. Int. Explor. Mer 150: 297-299.

Tuset, V., A. Lombarte \& C. Assis. 2008. Otolith atlas for the western Mediterranean, North and Central Eastern Atlantic. Sci. Marina 72: 7-198.

Volpedo, A. \& D.D Echeverria. 2003. Ecomorphological patterns of the sagitta in fish on the continental shelf off Argentine. Fish. Res. 60: 551-560.

Volpedo, A.V. \& G.A. Thompson. 1996. Diferencias en el crecimiento de las sagittae de Prionotus nudigula Ginsburg, 1950 (Pisces: Triglidae) en relación al sexo. Boletín del Instituto Español de Oceanografía 12: 3-16.

Waessle, J.A., C.A. Lasta \& M. Favero. 2003. Otolith morphology and body size relationships for juvenile Sciaenidae in the Rio de la Plata estuary $\left(35-36^{\circ} \mathrm{S}\right)$. Scientia Marina 67: 233-240.

Yañez, A.A. 1986. Ecology of the Coastal Zone. Analysis of Seven Topics. AGT Editor, Mexico. 
